\title{
Geology and Hydrostratigraphy of Guadalupe River State Park and Honey Creek State Natural Area, Kendall and Comal Counties, Texas
}

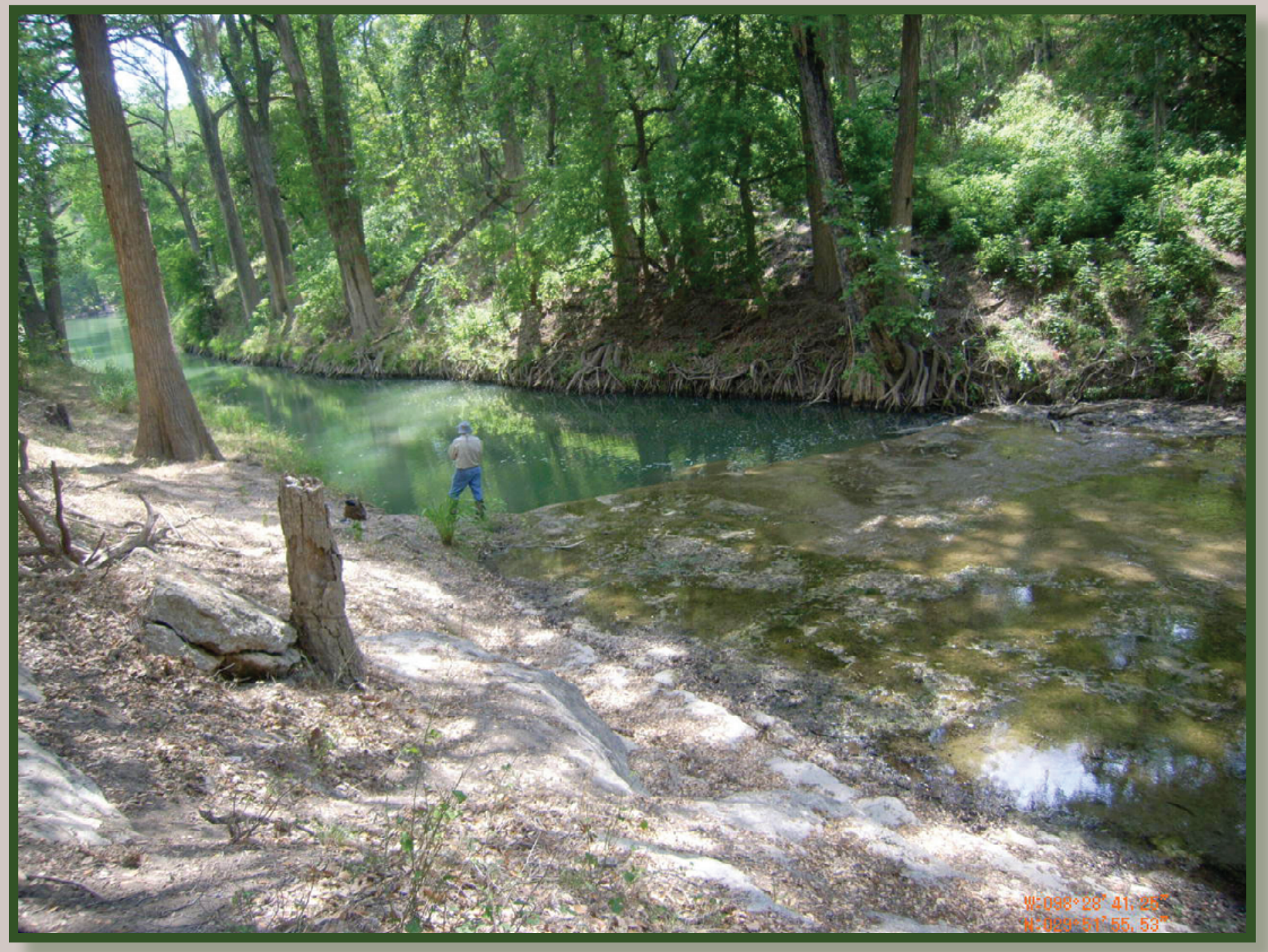

Pamphlet to accompany

Scientific Investigations Map 3303

U.S. Department of the Interior

U.S. Geological Survey 
COVER. North bank of Honey Creek looking downstream to the confluence with the Guadalupe River. Photo taken by Allan Clark, U.S. Geological Survey. 


\section{Geology and Hydrostratigraphy of Guadalupe River State Park and Honey Creek State Natural Area, Kendall and Comal Counties, Texas}

By Allan K. Clark, Charles D. Blome, and Robert R. Morris

Pamphlet to accompany

Scientific Investigations Map 3303 


\title{
U.S. Department of the Interior SALLY JEWELL, Secretary
}

\section{U.S. Geological Survey Suzette M. Kimball, Acting Director}

\author{
U.S. Geological Survey, Reston, Virginia: 2014
}

For more information on the USGS - the Federal source for science about the Earth, its natural and living resources, natural hazards, and the environment, visit http://www.usgs.gov or call 1-888-ASK-USGS.

For an overview of USGS information products, including maps, imagery, and publications, visit http://www.usgs.gov/pubprod

To order this and other USGS information products, visit http://store.usgs.gov

Any use of trade, firm, or product names is for descriptive purposes only and does not imply endorsement by the U.S. Government.

Although this information product, for the most part, is in the public domain, it also may contain copyrighted materials as noted in the text. Permission to reproduce copyrighted items must be secured from the copyright owner.

Suggested citation:

Clark, A.K., Blome, C.D., and Morris, R.R., 2014, Geology and hydrostratigraphy of Guadalupe River State Park and Honey Creek State Natural Area, Kendall and Comal Counties, Texas: U.S. Geological Survey Scientific Investigations Map 3303, 8 p., 1 sheet, scale 1:24,000, http://dx.doi.org/10.3133/sim3303.

ISSN 2329-132X (online) 


\section{Contents}

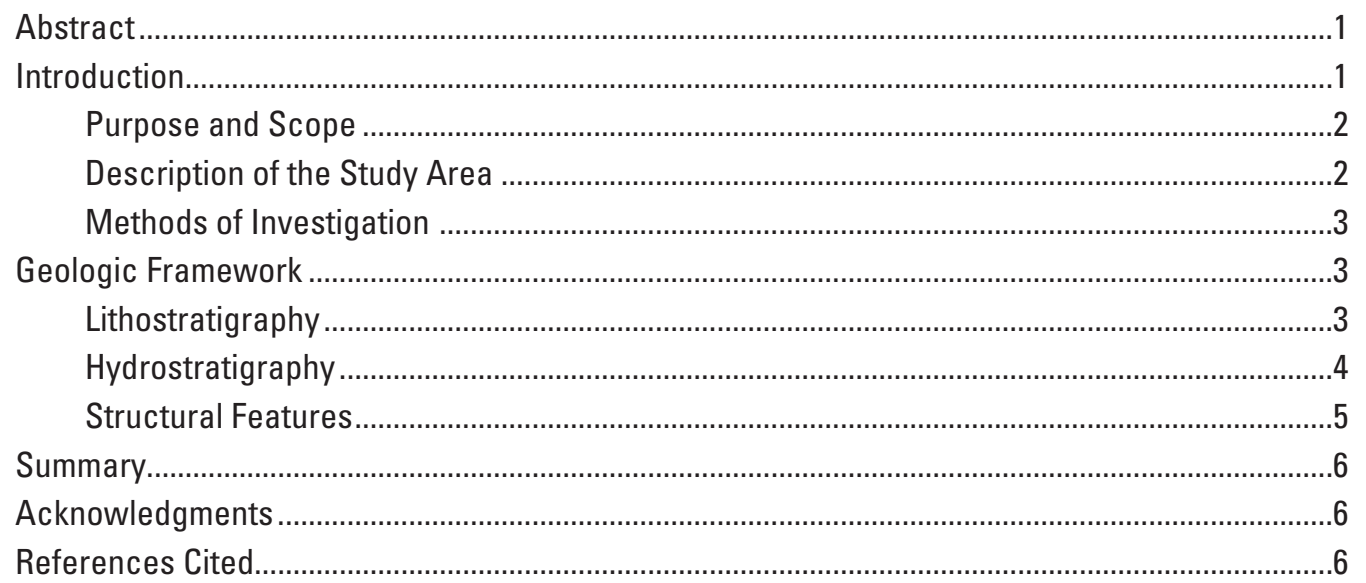

\section{Sheet}

1. Geology and Hydrostratigraphy of Guadalupe River State Park and Honey Creek State Natural Area, Kendall and Comal Counties, Texas .............................................. link 


\section{Conversion Factors}

\begin{tabular}{|c|c|c|}
\hline Multiply & By & To obtain \\
\hline \multicolumn{3}{|c|}{ Length } \\
\hline foot $(\mathrm{ft})$ & 0.3048 & meter $(\mathrm{m})$ \\
\hline mile (mi) & 1.609 & kilometer $(\mathrm{km})$ \\
\hline \multicolumn{3}{|c|}{ Flow rate } \\
\hline cubic foot per second $\left(\mathrm{ft}^{3} / \mathrm{s}\right)$ & 0.02832 & cubic meter per second $\left(\mathrm{m}^{3} / \mathrm{s}\right)$ \\
\hline
\end{tabular}

Vertical coordinate information is referenced to the North American Vertical Datum of 1988 (NAVD 88).

Horizontal coordinate information is referenced to the North American Datum of 1983 (NAD 83). Altitude, as used in this report, refers to distance above the vertical datum. 


\title{
Geology and Hydrostratigraphy of Guadalupe River State Park and Honey Creek State Natural Area, Kendall and Comal Counties, Texas
}

\author{
By Allan K. Clark, Charles D. Blome, and Robert R. Morris
}

\section{Abstract}

Hydrogeologic mapping and descriptions of the lithostratigraphy and hydrostratigraphy of Guadalupe River State Park and Honey Creek State Natural Area, Kendall and Comal Counties, Texas, are presented in this first detailed 1:24,000 geologic map, along with proposed names and descriptions of the hydrostratigraphic units in the study area. Variations in the amount and type of porosity of the lithostratigraphic unit, which vary depending on the depositional environment, lithology, structural history and diagenesis support the resulting hydrostratigraphy proposed herein.

Rocks exposed in the study area consist of Early Cretaceous sedimentary rocks that are assigned to the Trinity Group. The lithostratigraphy includes the Hammett Shale, Cow Creek Limestone, Hensell Sand Members of the Pearsall Formation, and the lower member of the Glen Rose Limestone. These lithologic units contain shale, grainstone, sandstone, and fossiliferous limestone, alternating and interfingering with mudstone, wackestone, packstone, and grainstone.

The Trinity aquifer hydrostratigraphic units shown on the map and described herein are characterized by their porosity types. Porosity types were first determined from an analysis of two boreholes conducted in comparison with 143 geophysical logs from northern Bexar County, Texas. The cores and geophysical log comparison resulted in division of the lower member of the Glen Rose Limestone into six hydrostratigraphic units, designated A through F. Of those six units, only three remain in the study area because of erosion. The proposed naming of these three hydrostratigraphic units is based on topographic or historical features that occur in the outcrop area of those units. Hydrostratigraphic units that correlate with the boundaries of the formation have been given formational names excluding the lithologic modifier. The Doeppenschmidt hydrostratigraphic unit is stratigraphically the highest interval in the study area, characterized by interparticle, moldic, burrowed, bedding plane, fracture, and cave porosity. The underlying Rust hydrostratigraphic unit appears to be a confining unit with springs/seeps issuing near the contact with the overlying Doeppenschmidt unit. The Rust unit has interparticle, fracture, and cave porosity with cave porosity primarily associated with faulting. The Honey Creek hydrostratigraphic unit is an aquifer in the subsurface and exhibits extremely, well developed porosity and permeability includinginterparticle, moldic, burrowed, bedding plane, fracture, channel, and cave porosity. This unit is named for Honey Creek Cave, which discharges water into Honey Creek. The Hensell hydrostratigraphic unit contains primarily interparticle porosity, but also exhibits some moldic and cave porosity in its upper parts. The Cow Creek hydrostratigraphic unit contains interparticle, moldic, vug, burrowed, fracture, bedding plane, channel, and cave porosity. The Cow Creek hydrostratigraphic unit is an aquifer in the subsurface and is the primary target for water-well drillers in the area. The Hammett hydrostratigraphic unit is not exposed in the study area but is thought to underlie parts of the Guadalupe River, based on mapping of the overlying units and comparisons with subsurface thicknesses obtained from the geophysical log. The Hammett unit restricts the downward migration of groundwater, resulting in springs that discharge at the base of the Cow Creek unit. These springs also create some base flow to the Guadalupe River during periods of extreme drought.

The faulting and fracturing in the study area are part of the Miocene Balcones Fault Zone, which is an extensional system of faults that generally trend southwest to northeast in south-central Texas. An igneous dike, containing aphanitic texture, cuts through the center of the study area near the confluence of Honey Creek and the Guadalupe River. The dike penetrates the Cow Creek Limestone and the lower part of the Hensell Sand, which outcrops at three locations.

\section{Introduction}

The study area is located in Guadalupe River State Park (GRSP) and the adjoining Honey Creek State Natural Area (HCSNA) in Kendall and Comal Counties, Texas (fig. 1), and is underlain by the Early Cretaceous Trinity Group. The GRSP 
is developed and provides camping sites for both recreational vehicles and tents, parking areas and restrooms for day-use visitors, picnic areas, river access points, and hiking trails. The adjacent HCSNA is undeveloped, with the exception of a few historic roads and buildings that are accessible by guided tours only. Both GRSP and HCSNA are administered by the Texas Parks and Wildlife Department (TPWD).

The Early Cretaceous Trinity Group consists of limestone, sand, clay, gravel, and conglomerate (George and others, 2011) that compose the Hosston Formation (Imlay, 1940), Sligo Formation (Warner and Moody, 1992), Pearsall Formation (Imlay, 1940), and the Glen Rose Limestone (Hill, 1891). The Pearsall Formation has been further subdivided into the Hammett Shale (Lozo and Stricklin, 1956), Cow Creek Limestone (Barnes, 1976), and Hensell Sand (Barnes, 1976), and the Glen Rose Limestone has been subdivided into a lower and upper member (Hill, 1891; Whitney, 1952). These rocks compose the entire Trinity aquifer, which is subdivided into the upper, middle, and lower Trinity aquifers (Ashworth, 1983).

According to Ashworth (1983), the upper Trinity aquifer is contained in the upper member of the Glen Rose Limestone, the middle Trinity aquifer is formed by the Cow Creek Limestone, Hensell Sand, and the lower member of the Glen Rose Limestone, and the lower Trinity aquifer is formed in the Hosston and Sligo Formations. The Hammett Shale is a confining unit between the lower and middle Trinity aquifers (Ashworth, 1983). However, in the study area, only the Hammett Shale, the Cow Creek Limestone, Hensell Sand, and part of the lower member of the Glen Rose Limestone, which compose the lower $80 \%$ of the Middle Trinity aquifer, are exposed at the surface.

Although the Trinity aquifer is classified as a major aquifer by the State of Texas, transmissivities and water yields can be comparatively lower than other aquifers in the area (Mace and others, 2000, and Maclay, 1995) resulting in other available sources of water being used. New development and increased drought conditions have combined to renew interest in the Trinity aquifer and concerns about groundwater availability (Mace and others, 2000).

The Trinity aquifer is a karst system formed from the dissolution of carbonate rocks by water. Distinctive landforms are created from the dissolution with numerous springs and karst features - caves, sinkholes, and other visible areas of solution-enlarged porosity. Karst features can have an appreciable effect on the hydrologic characteristics of an area because they can act as points of focused recharge (Hanson and Small, 1995; U.S. Geological Survey, 2011a). These same features that form in springs also result in an aquifer that is susceptible to contamination because storm-water runoff is quickly transferred to the subsurface (Ryan and Meiman, 1996).

\section{Purpose and Scope}

The purpose of this report is to document the results of hydrogeologic mapping between 2011 and 2012 in the GRSP and HCSNA. This report presents the first detailed 1:24,000 geologic map, and proposed names and descriptions of the hydrostratigraphic units in the study area. The mapping also provided an opportunity to determine if hydrogeologic characteristics of the Trinity aquifer rocks, located south of the study area in northern Bexar County (fig. 1; Clark and others, 2009), would be correlative in western Kendall and eastern Comal Counties. In addition, the report contains information on lithostratigraphy and hydrostratigraphy of the Hammett Shale, Cow Creek Limestone, Hensell Sand, and the lower member of the Glen Rose Limestone. Detailed hydrostratigraphic mapping of GRSP and HCSNA will aid the Texas Parks and Wildlife Department and other water managers in determining the effects and future development of groundwater resources in the study area. This study focuses on the outcrops of the Trinity aquifer rocks within the boundaries of the two parks.

\section{Description of the Study Area}

The study area is located in eastern Kendall and western Comal Counties, south-central Texas, about 25 miles (mi) north of the city of San Antonio (fig. 1). The study area contains approximately 4,230 contiguous acres of land that are almost evenly divided between GRSP, encompassing $46 \%$ of the study area (Texas Parks and Wildlife Department, 2012a); and the adjoining HCSNA, encompassing 54\% of the study area (Texas Parks and Wildlife Department, 2012b; pl. 1). The Guadalupe River flows through the northern part of the study area and forms parts of the eastern and western park borders (fig. 1, photograph 1). The Guadalupe River's mean flow obtained from 8.5 river-miles downstream from the eastern boundary of the study area (USGS site number 08167500; http://waterdata. usgs.gov/tx/nwis/uv/?site_no $=08167500 \&$ PARAmeter_cd $=00$ 065,00060,00062,72020,00054, accessed April 2, 2014), was 373 cubic feet per second (cfs).

The study area is characterized by steep-sided, narrow valleys, many of which contain seeps and springs. The drainage pattern is predominantly dendritic, although trellis patterns occur where faults and fractures control the drainage. These valleys have cut into the tableland of the Edwards Plateau (fig. 2) and contain tributaries that drain to the Guadalupe River.

The lower reach of Honey Creek is a spring-fed (George, 1952), perennial (Musgrove and others, 2010) tributary of the Guadalupe River. The spring flows from Honey Creek cave, a subsurface trellis cave system with long passages aligned in a southwest to northeast direction that is connected by shorter, cross-passages aligned in a southeast to northwest direction (George, 1952; Elliott and others, 1994). This cavern is the longest known cave in Texas with over 20 mi of mapped passages (Elliott, 2012). Honey Creek cave is not shown on the map, because it is outside the boundaries of the study area on private property. In addition, the cave location is not shown because of safety concerns; the cave contains flooded passages and reacts quickly to rain events and has the potential of trapping inexperienced explorers. 


\section{Methods of Investigation}

A geophysical well-log near the study area was correlated with geophysical logs from northern Bexar County. The units used herein were first identified during the analysis of geophysical logs and two borehole rock-cores from wells in northern Bexar County (fig. 3) by the senior authors of this study. The cores from northern Bexar County are currently stored at the USGS Core Research Center, Denver, Colo.

The field mapping was aided by an Apple iPad2, which contained geospatially registered $7.5^{\prime}$ USGS topographic maps and an integrated global positioning system. Attitudes of fractures and faults were measured using either a handheld compass or the iPad2 compass application, called GeoId. Data collected with the iPad2 was verified with a handheld compass. Bedding attitudes in the study area were horizontal or nearly horizontal, and are therefore not shown on the map. The field data were transferred to Esri ArcMap geographic information system (GIS), quality checked, and then used to produce the geologic map (pl. 1).

Lithologic and hydrostratigraphic descriptions are based on field observations as well as previously published reports, such as Stricklin and others (1971) and Amsbury (1974). Lithologic descriptions are based on Dunham's (1962) carbonate rock classification system that characterizes carbonate rocks based on their fabric. The fabric of a rock is defined as, "The orientation in space of the particles, crystals, and cement of which a sedimentary rock is composed" (Bates and Jackson, 1987, p. 232). The porosity of the rocks is identified as either fabric selective or not-fabric selective under the sedimentary carbonate rock classification system (table 1) of Choquette and Pray (1970). According to Choquette and Pray, porosity that develops because of textural and structural features of the rock is classified as fabric selective. If there is no relation between the porosity and fabric elements, the porosity is classified as not-fabric selective (table 1).

Faults shown on the geologic map are based on observed and inferred stratigraphic offsets; however, no fault planes were seen in the outcrop. Fractures depicted on the map are labeled as such because of the unusually long distances these fractures can be traced. The fractures do not show any displacement or stratigraphic offset, which is in contrast to the mapped faults. Strike and dip of fractures were also noted, and were imported into the Grapher v. 9 software package (Golden Software, Inc., 2003) to create a rose diagram (fig. 4).

\section{Geologic Framework}

Sediments that compose the Trinity Group rocks were deposited during the Early Cretaceous (table 1) on a large shallow-water platform that sloped to the south and southeast, away from the Llano Uplift. The southeastern edge of the uplift is about $30 \mathrm{mi}$ to the north of the study area. The Llano Uplift was aerially to subaerially exposed, and was a topographic high that supplied sediment to the ancestral Gulf of Mexico. The Trinity Group was deposited as a sequence of three, transgression-regression, clastic carbonate "couplets" on the shallow-water platform (Clark, 2004; Weirman and others, 2010). The three transgression-regression "couplets" include - (1) the deposition of the Hosston and Sligo Formations (not exposed in the study area; Imlay, 1940); (2) the deposition of the Hammett Shale and Cow Creek Limestone; and (3) the deposition of the Hensell Sand and Glen Rose Limestone (Clark, 2004; Weirman and others, 2010; table 1). These rock units contain shale, grainstone, sandstone, and fossiliferous limestone with alternating and interfingering mudstone, wackestone, packstone, and grainstone.

\section{Lithostratigraphy}

The stratigraphically, lowest mapped unit within the study area is the Pearsall Formation. The Pearsall Formation is composed of the Hammett Shale, Cow Creek Limestone, and Hensell Sand. The thickness of the Hammett Shale is based on geophysical logs and is estimated to be approximately 50 feet (ft) thick. The lower $15 \mathrm{ft}$ of the unit contain siltstone and dolomite. The upper $35 \mathrm{ft}$ are primarily claystone with sandstone lentils at the base and middle parts of the unit, and fossiliferous dolomitic limestone in the uppermost part of the unit (Lozo and Stricklin, 1956; Weirman and others, 2010). The contact of the Hammett Shale with the overlying Cow Creek Limestone is conformable (Weirman and others, 2010). Although not observed, the Hammett Shale is inferred to exist in the topographically lower sections of the Guadalupe River valley and its tributaries, in the northeastern part of the map area, based on comparisons of stratigraphic thicknesses and elevation changes. The Cow Creek Limestone is approximately $72 \mathrm{ft}$ thick in the study area. This thickness is based on a geophysical log of well DX-68-13-209 (fig. 3), located approximately $0.5 \mathrm{mi}$ from the eastern boundary of the study area and about $2.5 \mathrm{mi}$ southeast of the Cow Creek Limestone exposed along Honey Creek. Weirman and others (2010) subdivided the Cow Creek Limestone into a lower dolomitic unit and an upper grainstone unit, herein referred to as the lower member of the Cow Creek Limestone and upper member of the Cow Creek Limestone, respectively.

The lower member of the Cow Creek Limestone is about $14 \mathrm{ft}$ thick based on the geophysical log of well DX-68-13209 (fig. 3), and is composed of dolomitic oyster mudstone to wackestone that grades upward to a dolomitic oyster wackestone to packstone (Weirman and others, 2010). In outcrop, the lower part of the Cow Creek Limestone is softer and more easily eroded, resulting in a cutback that is overlain by the more massive and resistant upper part (photograph 2). Field observations have revealed that a mostly bioturbated, recrystallized, dolomitic mudstone occurs near the contact of the lower and upper parts.

The upper member of the Cow Creek Limestone is $58 \mathrm{ft}$ thick, based on both the geophysical log of well DX-6813-209 and field mapping. According to Weirman and others (2010), the upper member of the Cow Creek Limestone is a 
brown to white, very fine grained to fine grained carbonate sand grainstone with localized bedding. They also state that locally, the upper part is a white, well-sorted, fine- to mediumgrained carbonate sand grainstone that has been recrystallized. The top of the upper member of the Cow Creek Limestone contains depositional, trough cross-bedding (Weirman and others, 2010). The upper contact of the Cow Creek Limestone with the overlying Hensell Sand is considered to be unconformable (Weirman and others, 2010).

The Hensell Sand is approximately $40 \mathrm{ft}$ thick in the study area; however, the geophysical log (fig. 3) from well DX-68-13-209 indicates that the unit is $70 \mathrm{ft}$ thick in the subsurface, which correlates with its observed thickness in wells south of the study area in northern Bexar County (fig. 1). In its lower part, the Hensell Sand is a reddish claystone and siltstone which contains terrigenous sandstone, pelecypods, and fossil fragments. The pelecypods in the Hensell Sand commonly have beekite structures on the surface of the shell. Beekite is a chalcedony pseudomorph occurring as small rings on the surface of shells (Gary and others, 1977). These oysters are evidently a common occurrence as they were observed at various sites where the Hensell Sand is exposed in the study area. In addition, George (1952, p. 16) also noted the occurrence of the fossil exogyra that "...have concentric surface markings of secondary siliceous material (beekite)" in two different levels of the Hensell Sand. The upper part of the Hensell Sand is a nodular, fine-grained sandstone that contains quartz and feldspar grains, fossil fragments, fish teeth, and pelecypods that also commonly show beekite structures.

The Hensell Sand also contains quartz geodes, some of which are more than a foot in diameter. The quartz geodes appear to increase in abundance and size near the small igneous dike that is mapped in the northeastern part of the study area. The Hensell Sand conformably underlies the lower member of the Glen Rose Limestone (photograph 3), and commonly forms slopes between the Glen Rose Limestone and the underlying Cow Creek Limestone. Both the Glen Rose and the Cow Creek Limestones are more resistant to erosion and commonly form cliffs or ledges.

The lower member of the Glen Rose Limestone is approximately $260 \mathrm{ft}$ thick; however, within the study area the top of this formation has been eroded and only about $185 \mathrm{ft}$ of the lower portion remain. This $185 \mathrm{ft}$ remnant of the lower member of the Glen Rose Limestone was divided into three mappable unnamed lithostratigraphic units; which correlate to the three hydrostratigraphic units identified in the hydrostratigraphic section. The lower $55 \mathrm{ft}$ section of the Glen Rose Limestone contains a very thick to massive bed of a Toucasia sp. grainstone. The lower part of the unit commonly contains shell fragments, pecten, Turritella, and oyster species. At one location, a biostrome of unidentified coral crops, located above the base of the lower member of the Glen Rose Limestone, was traced laterally several hundred feet. The location of the biostrome is not shown to protect the site from collectors.

Above the lower massive bed of Toucasia sp. is approximately $70 \mathrm{ft}$ of alternating marl and mudstone. This $70 \mathrm{ft}$ unit is covered by soil and vegetation; however, ledges containing miliolid grainstone, grainstone, nodular bioturbated wackestone, and monoplurids protrude through the soil. Throughout this unit, pectens, oysters, pelecypods, Nerinia sp., Orbitolina sp., Tylostoma sp., and monoplurids can be found. Above the alternating beds of marl and mudstone is a massive limestone that forms cliffs at several locations. This massive limestone contains packstone to grainstone and fossil fragments. The massive limestone is overlain by alternating beds of marl and limestone. Collectively, the massive limestone and overlying marl and limestone are as much as $60 \mathrm{ft}$ thick in the study area.

\section{Hydrostratigraphy}

Hydrostratigraphic units have been mapped using the porosity-based classification system developed by Choquette and Pray (1970). According to Choquette and Pray, porosity that develops as a result of textural and structural features of the rock is classified as "fabric selective." If there is no relation between the porosity and fabric elements, the porosity is classified as "not-fabric selective." To characterize the hydrostratigraphic units shown on the map, only primary porosity types were used. The primary fabric selective porosity types identified in the study area are interparticle, moldic, burrowed, and bedding plane porosity. The primary not-fabric selective porosity types are fracture, channel, vug, or cave porosity.

These hydrostratigraphic units were observed in geophysical logs of boreholes in northern Bexar County that penetrated the middle Trinity aquifer (fig. 3 , table 1). The middle Trinity aquifer encompasses the lower member of the Glen Rose Limestone, the Hensell Sand and the Cow Creek Limestone from top to bottom (Ashworth, 1983) and ranges in thickness from 284 to $327 \mathrm{ft}$ in the study area. In the northern Bexar County area, the lower member of the Glen Rose Limestone could be divided into six hydrostratigraphic units from top to bottom, A through F. However, due to erosion, only a portion of hydrostratigraphic unit $\mathrm{D}$ and all of units $\mathrm{E}$ and $\mathrm{F}$ remain in the study area. The other hydrostratigraphic units are composed of the Hensell Sand, Cow Creek Limestone and the Hammett Shale. The current mapping effort did not subdivide the Hensell Sand, Cow Creek Limestone or Hammett Shale. The Hensell Sand, Cow Creek Limestone and Hammett Shale are referred to without their lithologic modifiers to differentiate between lithostratigraphic and hydrostratigraphic units. New names for the previously lettered D, E, and F units are herein proposed, based on topographic and historical features that are in the study area, and within those intervals.

The Doeppenschmidt hydrostratigraphic unit (formerly subdivision D; Kgrd) is the uppermost hydrostratigraphic unit present, and contains interparticle, moldic, burrowed, bedding plane, fracture, and cave porosity. This interval might be an aquifer in the subsurface based on identified lithology, porosity, and the presence of seeps and springs. The Doeppenschmidt unit was named after the Doeppenschmidt family and homestead, who were the original settlers of the land that 
would later become Honey Creek State Natural Area (Texas Parks and Wildlife Department, 2012b). Water for the Doeppenschmidt homestead issued from a spring(s) at the base of the unit.

The Rust hydrostratigraphic unit (Kgrr) directly underlies the Doeppenschmidt unit, and has interparticle, fracture, and cave porosity. This hydrostratigraphic unit appears to be a barrier to subsurface flow, because springs and seeps flow from near its contact with the overlying Doeppenschmidt unit. Fracture porosity is not well developed in this unit because of the high marl content, but several of the thicker limestone beds have well developed fractures that may have undergone solution enlargement. The Rust unit contains cave porosity primarily near faults (pl. 1). The Rust unit was named for the Rust homestead in GRSP.

The Honey Creek hydrostratigraphic units (Kgrhc; photograph 4) is the lowest hydrostratigraphic interval in the lower Glen Rose Limestone, and contains interparticle, moldic (photograph 5), burrowed, bedding plane, fracture, channel, and cave porosity. A few feet above the base of this massive lower section is a $\sim 1-2 \mathrm{ft}$ thick band with conspicuous moldic porosity. This hydrostratigraphic unit is water-bearing in the subsurface and exhibits well developed porosity and permeability. The Honey Creek cave system, which is the longest explored cave system in Texas at over $20 \mathrm{mi}$ (Texas Speleological Survey, 2012), discharges water into Honey Creek from this hydrostratigraphic unit. The unit was named for Honey Creek Cave.

The Hensell hydrostratigraphic unit (Kheh) contains primarily interparticle porosity in its upper part. Moldic and cave porosity can be found throughout the unit. The cave porosity is likely associated with roof collapse of one or more underlying caves in the Cow Creek unit. This unit consists mostly sand suggesting it is most likely is a water-bearing unit in the subsurface. The Hensell unit was named for the Hensell Sand.

The Cow Creek hydrostratigraphic unit (Kcccc; photographs 6 and 7) contains interparticle, moldic, vug, burrowed, fracture, bedding plane, and channel, and cave porosity. This hydrostratigraphic unit is water-bearing in the subsurface and is the primary interval for water-well drilling in the area. The Cow Creek unit was named for the Cow Creek Limestone.

The Hammett hydrostratigraphic unit (Khah) is not exposed in the study area; however, it is shown on the map where it is inferred to underlie thin, unmapped alluvium and colluvium along the Guadalupe River. The interval is a confining unit based on field observations and data reported by Ashworth (1983) and Weirman and others (2010), which restricts the downward migration of groundwater resulting in springs forming near the base of the overlying Cow Creek unit. These springs contribute to the base flow that supplies the Guadalupe River with water over periods of low rainfall. The Hammett unit was named for the Hammett Shale lithostratigraphic unit.

\section{Structural Features}

Faulting and fracturing in the study area are part of the Miocene Balcones fault zone (BFZ). This fault zone is thought to be an extension of the Ouachita structural belt which underlies most of central Texas (Caran and others, 1982). The BFZ is an extensional system of faults that generally trends southwest to northeast in south-central Texas. These normal faults are en echelon in outcrop and dip to the southeast. Variation in the strikes and dips of the faults in the outcrop is a result of stress-strain variations of the different rocks that are faulted (Clark, 2004).

A rose diagram, which is a circular histogram plot of directional data and frequency, was generated for 84 measured fractures (fig. 4). The primary fracture orientation is northeast to southwest and averages about 45 degrees, conjugate fractures were at 150 degrees which is consistent with the BFZ. These values for the primary and conjugate fractures are consistent with Wermund and others (1978) who derived the regional distribution of fractures for most of the BFZ using controlled aerial photograph mosaics. A second set of fractures trend 113 degrees and 68 degrees, and are most likely related to intrusion of the igneous dike, changes or variations in primary BFZ faulting, or possible karst collapses. The four fractures shown on the map (pl. 1) are composed of abundant parallel fractures that can be followed on the ground for the length of the trace indicated on the map. A comparison of the surface drainage patterns and mapped cave passages of Honey Creek Cave (not shown in report) suggest that the BFZ-related fractures and faults ( 45 degrees) may form the primary pathways for both surface and groundwater flow. The conjugate fractures (150 degrees) might form the link between the primary flow paths, allowing water to move from one drainage/conduit to the next parallel passage in a networking drainage pattern.

The igneous dike of Early Cretaceous age or younger cuts through the center of the study area near the confluence of Honey Creek and the Guadalupe River (photograph 8, pl. 1). The dike penetrates the Cow Creek Limestone and the lower part of the Hensell Sand, and is visible at three locations. The best exposure is in the Cow Creek Limestone along Honey Creek, approximately $300 \mathrm{ft}$ upstream from the confluence of the creek with the Guadalupe River (photograph 8). At this location, the dike is columnar jointed and appears to be dipping slightly to the north. The actual dip of the dike is not possible to determine based on surface observations because weathering resulted in more of a transitional contact with the Cow Creek Limestone. Quartz geodes (photograph 9) are common throughout the Hensell Sand, but become more abundant near the dike. 


\section{Summary}

This report presents the first detailed 1:24,000 geologic map, and proposes names and descriptions of the hydrostratigraphic units in Guadalupe River State Park and Honey CreekState Natural Area, Kendall and Comal Counties, Texas. The newly defined hydrostratigraphy was based on the amount and type of porosity in each lithostratigraphic unit. The amount and type of porosity varies depending on the unit's depositional environment, lithology, structural history, and diagenesis.

The rocks exposed in the study area are Early Cretaceous sedimentary rocks that belong to the Trinity Group. These formations contain shale, grainstone, sandstone, and fossiliferous limestone, with alternating and interfingering mudstone, wackestone, packstone, and grainstone. The hydrostratigraphic units were determined by mapping the lithostratigraphic units and applying porosity characteristics from the classification system developed by Choquette and Pray (1970). The assigned hydrostratigraphic unit names are based on and consistent with topographic or historical features that occur in the study area.

South of the study area, the lower member of the Glen Rose Limestone was divided into six hydrostratigraphic units based on geophysical logs and borehole core analysis. In the study area, erosion has removed the upper three and part of the fourth hydrostratigraphic unit. The remaining portion of the lower Glen Rose Limestone was divided into three hydrostratigraphic units, the Doeppenschmidt, Rust, and Honey Creek. The Doeppenschmidt unit (Kgrd) is the uppermost hydrostratigraphic unit present in the study area, and is characterized by interparticle, moldic, burrowed, bedding plane, fracture, and cave porosity. The Rust unit (Kgrr) has interparticle, fracture, and cave porosity; however, it appears to be a confining unit because springs and seeps flow from near the contact with the overlying Doeppenschmidt unit. The Honey Creek hydrostratigraphic unit (Kgrhc) contains interparticle, moldic, burrowed, bedding plane, fracture, channel, and cave porosity. The Honey Creek unit is water bearing in the subsurface and exhibits well-developed porosity and permeability. The Honey Creek Cave system, which is the longest explored cave (20 mi) in Texas resides in this unit and discharges water into Honey Creek.

The Hensell unit (Kheh) contains primarily interparticle porosity in its upper part, it also contains some moldic and cave porosity in its lower parts. Based on field observations, this unit is probably water bearing. The Cow Creek unit (Kcccc) contains interparticle, moldic, vug, burrowed, fracture, bedding plane, channel, and cave porosity. It is a waterbearing interval in the subsurface and is the primary target for water-well drilling in the area. The Hammett unit (Khah) is not exposed in the study area, but is inferred to underlie parts of the Guadalupe River in the northern part of the map area based on field mapping, geophysical logs, and the presence of seeps and springs that issue from the flanks of the river channel. The Hammett Shale restricts the downward migration of groundwater, which results in seeps and springs issuing from the base of the overlying Cow Creek unit that augment the base flow of the Guadalupe River in periods of low rainfall.

Faulting and fracturing in the study area is part of the Miocene Balcones fault zone, which is an extensional system of faults that generally trend southwest to northeast in southcentral Texas. An igneous dike of Early Cretaceous age or younger cuts through the center of the study area near the confluence of Honey Creek and the Guadalupe River. The igneous dike cuts the Cow Creek Limestone and the lower part of the Hensell Sand, which is visible at three locations.

\section{Acknowledgments}

The authors thank Scott Taylor of the Texas Parks and Wildlife Department, Superintendent of Guadalupe River State Park and Honey Creek State Natural Area, and his staff for courtesies extended during field mapping. We also thank Dave Lidke, Marcus Gary, and Tom Judkins for their critical reviews.

\section{References Cited}

Amsbury, D. L., 1974, Stratigraphic petrology of lower and middle Trinity rocks on the San Marcos platform, southcentral Texas, in B. F. Perkins, ed., Aspects of Trinity Geology: Geoscience and Man, v. 8, p. 1-35.

Ashworth, J.B., 1983, Ground-water availability of the Lower Cretaceous formations in the Hill Country of south-central Texas: Texas Department of Water Resources Report 273, $172 \mathrm{p}$.

Ashworth, J.B., and Hopkins, Janie, 1995, Aquifers of Texas: Texas Water Development Board Report 345, 69 p.

Barker, R.A., and Ardis, A.F., 1996, Hydrogeological framework of the Edwards-Trinity aquifer system, west-central Texas: U.S. Geological Survey Professional Paper 1421-B, $61 \mathrm{p}$.

Barnes, V.E., 1974, Geologic atlas of Texas, San Antonio Sheet-Robert Hamilton Cuyler memorial edition: University of Texas-Austin, Bureau of Economic Geology, 1 sheet, scale 1:250,000.

Barnes, V.E., 1976, Geologic atlas of Texas, Crystal CityEagle Pass sheet-Dolan Hoye Eargle memorial edition: University of Texas-Austin, Bureau of Economic Geology, 1 sheet, scale 1:250,000.

Bates, R.L., and Jackson, J.A., eds., 1987, Glossary of Geology (3d ed.)—American Geological Institute: New York, N.Y., $576 \mathrm{p}$. 
Bebout, D.G., Budd, D.A., and Schatzinger, R.A., 1981, Depositional and diagenetic history of the Sligo and Hosston Formations (Lower Cretaceous) in south Texas: Austin, University of Texas, Bureau of Economic Geology Report of Investigations, no. 109, $70 \mathrm{p}$.

Caran, S. C., Woodruff, C. M., Jr., and Thompson, E. J., 1982, Lineament analysis and inference of geologic structureExamples from the Balcones/Ouachita trend of Texas, University of Texas-Austin, Bureau of Economic Geology Geological Circular 82-1, p. 59-69.

Choquette, P.W., and Pray, L.C., 1970, Geologic nomenclature and classification of porosity in sedimentary carbonates: American Association of Petroleum Geologists Bulletin, v. 54, no. 2, p. 207-250.

Clark, A.K., 2003, Geologic framework and hydrogeologic features of the Glen Rose Limestone, Camp Bullis Training Site, Bexar County, Texas: U.S. Geological Survey Scientific Investigations Report 2003-4081, 14 p., 1 pl., scale $1: 24,000$.

Clark, A.K., 2004, Geologic framework and hydrogeologic characteristics of the Glen Rose Limestone, Camp Stanley Storage Activity Area, Bexar County, Texas: U.S. Geological Survey Scientific Investigations Map 2831, scale 1:24,000.

Clark, A.R., Blome, C.D., and Faith, J.R., 2009, Map showing the geology and hydrostratigraphy of the Edwards aquifer catchment area, northern Bexar County, south-central Texas: U.S. Geological Survey Open-File Report 2009-1008, 24 p., 1 pl.

Dunham, R.J., 1962, Classification of carbonate rocks according to depositional texture, in Ham, W.E., ed., Classification of Carbonate Rocks: American Association of Petroleum Geologists Memoir 1, p. 108-121.

Elliott, W.R., 2012, CAVES in Handbook of Texas Online: Texas State Historical Association, accessed August 08, 2012, at http://www.tshaonline.org/handbook /online/ articles/rqc03.

Elliott, W.R., and Veni, G., eds., 1994, The caves and karst of Texas-1994 National Speleological Society Convention Guidebook: National Speleological Society, 342 p.

Gary, Margaret, McAfee, Robert, Jr., and Wolf, C.L., eds., 1977, Glossary of Geology: Falls Church, Va., American Geological Institute, 805 p.

George, P.G., Mace, R.E., and Petrossian, Rima, 2011, Aquifers of Texas, Texas Water Development Board Report 380: Austin, Tex., $172 \mathrm{p}$.
George, W.O., 1952, Geology and ground-water resources of Comal County, Texas, with sections on surface-water supplies and chemical character of the water: U.S. Geological Survey Water Supply Paper 1138, 126 p.

Grapher v. 9, 2003: Golden Software, Inc., accessed May 28, 2003, at http://www.goldensoftware.com/Products/grapher/ grapher.shtml.

Hanson, J.A., and Small, T.A., 1995, Geologic framework and hydrogeologic characteristics of the Edwards aquifer outcrop, Hays County, Texas: U.S. Geological Survey Water Resources Investigations Report 95-4265, 10 p.

Hill, R.T., 1891, The Comanche series of the Texas-Arkansas region: Geological Society of America Bulletin, v. 2, p. 503-528.

Imlay, R.W., 1940, Lower Cretaceous and Jurassic formation of southern Arkansas and their oil and gas possibilities: Arkansas Geological Survey Information Circular 12, 64 p.

Inden, R. F., 1974, Lithofacies and depositional model for a Trinity Cretaceous sequence, central Texas, in B. F. Perkins, ed., Aspects of Trinity Geology: Geoscience and Man, v. 8, p. 37-52.

Lozo, F.E., and Stricklin, F.L., Jr., 1956, Stratigraphic notes on the outcrop basal Cretaceous, central Texas: Gulf Coast Association of Geological Societies Transactions, v. 6, p. 67-78.

Lucia, F.J., 1995, Rock-fabric/petrophysical classification of carbonate pore space for reservoir characterization: American Association of Petroleum Geologists Bulletin, v. 79, no. 9 , p. 1275-1300.

Mace, R.E., Chowdhury, A.H., Anaya, Roberto, and Way, S.C., 2000, Groundwater availability of the Trinity Aquifer, Hill Country area, Texas-Numerical simulations through 2050: Texas Water Development Board Report 353: Austin, $111 \mathrm{p}$.

Maclay, R.W., 1995, Geology and hydrology of the Edwards Aquifer in the San Antonio area, Texas: U.S. Geological Survey Water-Resources Investigations Report 95-4186, 64 p., 12 pl.

Mancini, E.A., and Scott, R.W., 2006, Sequence stratigraphy of Comanchean Cretaceous outcrop strata of northeast and south-central Texas-Implications for enhanced petroleum exploration: Gulf Coast Association of Geological Societies Transactions, v. 56, p. 539-550.

Musgrove, M., Stern, L.A., and Banner, J.L., 2010, Springwater geochemistry at Honey Creek State Natural Area, central Texas-Implications for surface water and groundwater interaction in a karst aquifer: Journal of Hydrology, v. 388, p. 144-156. 
Perkins, B.F., 1974, Paleoecology of a rudist reef complex in the Comanche Cretaceous Glen Rose Limestone of central Texas, in B. F. Perkins, ed., Aspects of Trinity Geology: Geoscience and Man, v. 8, p. 131-173.

Rose, P.R., 1972, Edwards Group, surface and subsurface, central Texas: University of Texas-Austin, Bureau of Economic Geology Report of Investigations RI-74, 198 p.

Ryan, Martin, and Meiman, Joe, 1996, An examination of short-term variations in water quality at a karst spring in Kentucky: Ground Water, v. 34, p. 23-30.

Stricklin, F.L., Jr., and Smith, C.I., 1973, Environmental reconstruction of a carbonate beach complex, Cow Creek (Lower Cretaceous) Formation of central Texas: Geological Society of America Bulletin, v. 84, no. 4, p. 1349-1368.

Stricklin, F.L., Jr., Smith, C.I., and Lozo, F.E., 1971, Stratigraphy of Lower Cretaceous Trinity deposits of central Texas: University of Texas-Austin, Bureau of Economic Geology Report of Investigations 71, $63 \mathrm{p}$.

Texas Parks and Wildlife Department, 2012a, Description of Guadalupe River State Park, accessed April 30, 2012, at http://www.tpwd.state.tx.us/state-parks/guadalupe-river/ park_history.

Texas Parks and Wildlife Department, 2012b, Description of Honey Creek Natural Area, accessed April 30, 2012, at http://www.tpwd.state.tx.us/state-parks/honey-creek/ park_history.

Texas Speleological Survey, 2012, Overview of Texas Caves and Karst, accessed March 28, 2012, at http://www.utexas. edu/tmm/sponsored_sites/tss/cavesandkarst/index.html.

U.S. Geological Survey, 2011a, USGS groundwater information-What is karst, accessed April 11, 2011, at http://water. usgs.gov/ogw/karst/pages/whatiskarst.

U.S. Geological Survey, 2011b, USGS water data reports, accessed August 6, 2011, at http://waterdata.usgs.gov/tx/ nwis/uv/?site_no $=08167500 \&$ PARAmeter_cd $=00065,00060$, $00062,72020,00054$

Warner, A.J., and Moody, J.S., 1992, West Raymond field [Mississippi]: Mississippi Geology, v. 13, no. 2, p. 13-22

Weirman, D.A., Broun, A.S., and Hunt, B.B., 2010, Hydrogeologic Atlas of the Hill Country Trinity Aquifer, Blanco, Hays, and Travis Counties, Central Texas: Prepared by the Hays-Trinity, Barton Springs/Edwards Aquifer, and BlancoPedernales Groundwater Conservation Districts, July 2010, 17 pl. [DVD].

Wermund, E.G., 1996, Physiographic map of Texas: Bureau of Economic Geology Map SM0005, scale 1:6,336,000.
Wermund, E.G., Cepeda, J.C., and Luttrell, P.E., 1978, Regional distribution of fractures in the southern Edwards Plateau and their relationship to tectonics and caves: University of Texas-Austin, Bureau of Economic Geology Geological Circular, v. 78-2, 14 p.

Whitney, M.I., 1952, Some zone marker fossils of the Glen Rose Formation of central Texas: Journal of Paleontology, v. 26 , no. 1 , p. $65-73$

Publishing support provided by: Denver Publishing Service Center

For more information concerning this publication, contact: Director, USGS Texas Water Science Center 1505 Ferguson Lane, Austin TX 78754-4501

(512) $927-3500$

Or visit the Texas Water Science Center Web site at: http://tx.usgs.gov/ 


\section{$\frac{1}{4}$}

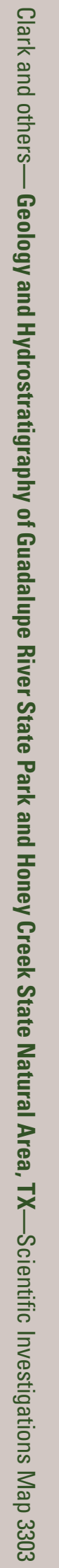

